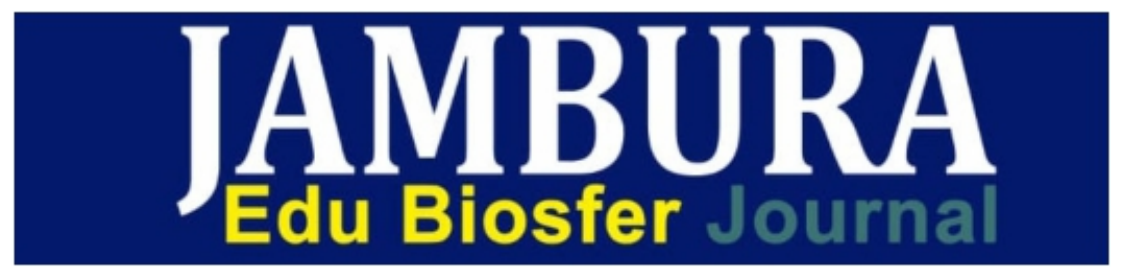

Journal homepage: http://ejurnal.ung.ac.id/index.php/edubiosfer

\title{
IDENTIFIKASI BAKTERI ASAM LAKTAT PADA NIRA SEGAR LONTAR (Borassus flabellifer Linn)
}

\section{Surenshy Bulu, Mellissa E.S Ledo, Anggreini D.N. Rupidara}

Program Studi Pendidikan Biologi, Fakultas Keguruan Dan Ilmu Pendidikan, Universitas Kristen Artha Wacana Kupang Jln. Adisucipto PO.BOX 147 Oesapa Kupang. NTT Telp (0380) 81169 e-mail :adn.rupidara@gmail.com, surenshyb@gmail.com

\begin{abstract}
ABSTRAK
Tujuan penelitian ini untuk mengidentifikasi karakteristik BAL pada nira segar lontar (Borassus flabellifer Linn). Metode dalam penelitian ini menggunakan eksperimental desain yang terdiri dari 2 tahap, tahap isolasi dan tahap konfirmasi. Data dianalisis secara desktiptif kuantitatif. Hasil penelitian mengidentifikasi morfologi BAL dari nira segar Borassus fabellifer Linn diperoleh empat isolat tunggal BAL. Karakteristik bakteri BAL yang diperoleh sebagai berikut:1)N1 A bentuk basil pendek, gram negatif, katalase positif, mesofilik; 2) N1в bentuk kokus, gram positif, katalase positif, mesofilik; 3) N1C bentuk basil panjang, gram negatif, katalase positif, mesofilik; 4) N2 bentuk basil panjang, gram positif, katalase positif, mesofilik. Berdasarkan karakteristik morfologi maka ke-empat isolat BAL diduga adalah genus Lactobacillus, Enterococcus, Leuconostoc, Streptococcus dan Pediococcus. Analisis genetika perlu dilakukan sebagai uji konfirmasi isolat-isolat yang didapat. Kata Kunci : Bakteri Asam Laktat, Nira Segar Lontar, Morfologi
\end{abstract}

\section{Pendahuluan}

Pohon lontar (Borassus flabellifer Linn) merupakan tanaman multiguna yang banyak tumbuh dan tersebar hampir di seluruh wilayah Indonesia (Nuroniah, 2010). Pohon lontar memiliki banyak kegunaan, antara lain buahnya dapat dimakan dan tandan bunga jantannya dapat disadap niranya. Nira lontar adalah suatu minuman alami yang terasa manis karena mengandung gula. Kandungan gula pada nira yaitu 12,3017,4 \% (Qonita dkk, 2018).

Minuman nira lontar memiliki rasa yang sangat khas dan dalam keadaan segar rasanya sangat manis, berbau harum, jernih dan tidak berwarna. Rasa manis minuman nira lontar disebabkan oleh tingginya kadar gula dalam nira tersebut. Tingginya kadar gula disertai adanya kandungan mikronutrien esensial lain menyebabkan nira lontar menjadi media pertumbuhan mikroba, seperti bakteri sehingga tidak tahan disimpan lama.

Setelah beberapa jam turun sadap, cairan nira mulai mengalami fermentasi spontan karena adanya mikroorganisme kontaminasi seperti Bakteri Asam laktat (BAL). Salah satu bakteri yang dapat tumbuh pada nira segar lontar (Borassus fabellifer Linn) adalah Bakteri Asam Laktat (BAL). BAL adalah bakteri yang telah lama dikenal dan dimanfaatkan oleh manusia dalam proses pengolahan bahan pangan melalui proses fermentasi. BAL yang diduga terdapat pada nira yang segar yang baru disadap adalah bakteri Leuconostoc dan Lactobacillus sp (Cahyaningsih, 2006; Ouoba et al. 2012).

BAL merupakan bakteri yang memiliki banyak manfaat antara lain berperan dalam fermentasi asam laktak dan probiotik (Surono, 2004), juga dapat menghambat pertumbuhan patogen dan bakteri pembusuk, 
menghasilkan hidrogen peroksida yang bersifat antibakteri (Suriawiria, 1995); menghasilkan bakteriosin yang berfungsi sebagai zat antibiotik (Jenie dan Rini, 1995). Karena manfaat tersebut maka penelitian ini bertujuan untuk mengidentifikasi karakteristik BAL pada nira segar lontar (Borassus flabellifer Linn).

\section{Metodologi}

\subsection{Waktu dan Tempat penelitian}

Penelitian ini telah dilaksanakan pada tanggal 19 Januari 2019 - 28 Februari 2019 di Laboratorium Mikrobiologi Pendidikan Biologi, Fakultas Keguruan dan Ilmu Pendidikan, Universitas Kristen Artha Wacana Kupang.

\subsection{Alat dan bahan penelitian}

Alat yang digunakan dalam penelitian ini adalah labu ukur volume larutan; gelas kimia, autoklaf, timbangan analitik, Erlenmeyer, oven, lemari, rak tabung, gelas ukur, lampu Bunsen/pemanas spiritus, pipet tetes,batang pengaduk/magnetic stirrer, dryglasky, cawan petri dan tabung reaksi, kaca mikroskop, jarum ose, penggaris, colony counter, kamera digital, kertas label, alat tulis.

Bahan yang digunakan dalam penelitian ini adalah nira lontar segar, aquades, pencampur zat, alkohol 70\%, alkohol 95\%, lugol's iodine, crystal violet, Safranin, Hydrogen peroxide, media NA, media Agar MRS, $\mathrm{NaCl}$, tissue.

\subsection{Metode penelitian}

Metode penelitian adalah deskriptif kuantitatif dengan teknik ekperimental yang dikerjakan dalam dua tahap yaitu tahap pertama mengisolasi Bakteri Asam Laktat (BAL) dari nira lontar segar sadapan pagi dan tahap kedua mengidentifikasi BAL hasil isolasi hingga genus BAL tunggal (Qonita dkk, 2018).

\subsection{Prosedur penelitian}

\section{Sterilisasi alat}

Semua alat yang digunakan dicuci bersih dan dibilas dengan alkohol dan disterilkan dengan oven pada suhu $160_{0} \mathrm{C}$ selama 60 menit.

\section{Pembuatan Media Pertumbuhan ( $g$ L-1)}

Sebanyak 4 gr media NA dilarutkan dalam aquades sebanyak $200 \mathrm{ml}$ dituang ke dalam gelas kimia dan kemudian dihomogenkan menggunakan magnetic stirrer di atas hot plate. Setelah homogen, medium disterilkan menggunakan autoklaf pada suhu $1210 \mathrm{C}$ selama 30 menit dengan tekanan $0.1 \mathrm{~atm}$.

Medium MRS dibuat dengan menimbang 13,6 g yang dilarutkan dalam $200 \mathrm{ml}$ akuades. Medium dihomogenkan dengan magnetic stirrer di atas hot plate. Setelah homogen disterilkan menggunakan autoklaf pada suhu $1210 \mathrm{C}$ selama 30 menit dengan tekanan $0,1 \mathrm{~atm}$.

\section{Pengambilan sampel}

Sampel nira segar sebanyak $1 \mathrm{~L}$ diambil dari nira sadapan pada jam 07.00 pagi di daerah pantai Oesapa. Nira yang diperoleh, disaring dan dituang dalam botol steril, kemudian dimasukkan ke dalam coolbox dan dibawa ke Laboratorium Mikrobiologi Pendidikan Biologi untuk dianalisa.

\section{Isolasi mikroba}

Nira segar yang diperoleh disaring dan diambil sebanyak $1 \mathrm{ml}$ untuk diisolasi ke medium NA pada cawan petri dengan metode pour plate. Sampel diinkubasikan menggunakan oven pada suhu 370C selama 48 jam.

5. Pemurnian isolat awal

Isolat yang tumbuh pada medium NA dilakukan pemurnian bertahap hingga diperoleh isolat tunggal.

\section{Pengenceran mikroba}


Isolat tunggal yang tumbuh pada medium NA dikarakterisasi secara morfologi kemudian dilakukan seri pengenceran dengan menggunakan larutan $\mathrm{NaCl}$ hingga memperoleh konsentrasi mikroba 10-6. Pengenceran dilakukan untuk mengurangi padatan bakteri yang ditanam (Qonita dkk, 2018).

\section{Identifikasi BAL}

Setiap isolat tunggal yang diperoleh dari medium NA selanjutnya diseleksi pada medium selektif MRS dengan mengambil 1 ose dari seri pengenceran $10_{-4}, 10_{-5}$ dan 10-6 untuk diidentifikasi berdasarkan karakteristik morfologi.

\section{Pengujian konfirmasi BAL}

Setelah pengenceran mikroba, isolasi BAL dilakukan dengan menggunakan media selektif Agar MRS. Penanaman bakteri dilakukan dengan memindahkan kultur bakteri dari seri pengenceran 10-4-10-6 masingmasing sebanyak 0,1 $\mathrm{ml}$ ke medium selektif Agar MRS sebagai uji konfirmasi BAL (Putri dkk, 2015). Bakteri yang tumbuh dilakukan konfirmasi karakteristik setiap isolat.

Koloni yang tumbuh dihitung total koloni menggunakan rumus:

$$
\mathrm{CFU}=\text { total koloni BAL } \mathrm{X}^{\overline{1} \# \$ \% \# \$ \& \#^{\prime}(\$)} \frac{!}{*_{+,-. \# \mathrm{O}(.1 \#,}}
$$

(Fachrial dkk, 2018)

\subsection{Analisis Data}

Data dianalisis secara deskriptif kualitatif menggunakan karateristik morfologi koloni berupa: bentuk, warna, permukaan, tepi, elevasi dan tekstur (Christoper dan Bruno, 2003); Pewarnaan gram (Qonita dkk, 2018 ); Uji biokimia yaitu Uji katalase dan Uji pertumbuhan pada suhu yang berbeda (Qonita dkk, 2018).

\section{Hasil dan Pembahasan}

Berdasarkan hasil penelitian pada media NA diperoleh bahwa karakter isolate yang tumbuh menunjukkan adanya 2 isolat yaitu: N1 dan N2. Ciri morfologi N1 berwarna putih susu, bentuk bulat, permukaan rough, tepi lobus, elevasi convex; N2 berwarna putih krem, bentuk bulat, permukaan smooth shiny, tepi entire, elevasi raised. Pada uji konfirmasi menggunakan media selektif Agar MRS ditemukan bahwa isolat N1 memiliki beberapa karakter spesifik yang berbeda sehingga disimpulkan bahwa N1 terdiri dari 3 koloni dengan masing-masing karakter yang spesifik sedangkan isolat N2 sudah merupakan koloni tunggal. Karakteristik masing-masing isolat dicirikan pada tabel 1.

Tabel 1. Uji Morfologi BAL dari segar lontar ( Borassus flabellifer Linn) pada media Agar MRS

\begin{tabular}{|c|c|c|c|c|c|c|c|c|c|c|}
\hline \multirow[b]{2}{*}{ Isolat } & & \multicolumn{6}{|c|}{ Morfologi } & \multicolumn{3}{|c|}{ Uji Biokimia } \\
\hline & Gram & $\begin{array}{c}\text { Bentuk } \\
\text { sel }\end{array}$ & $\begin{array}{l}\text { Bentuk } \\
\text { koloni }\end{array}$ & $\begin{array}{l}\text { Warna } \\
\text { koloni }\end{array}$ & Permukaan & Tepi & Elevasi & Tekstur & Katalase & $\begin{array}{l}\text { Suhu } \\
(\mathrm{T} / \mathrm{M})\end{array}$ \\
\hline $\mathrm{N} 1 \mathrm{~A}$ & Negatif & $\begin{array}{l}\text { Basil } \\
\text { pendek }\end{array}$ & Irregular & $\begin{array}{l}\text { Putih } \\
\text { susu }\end{array}$ & Rough & Lobus & Convex & Dry & ++ & $\mathrm{M}$ \\
\hline N1в & Positif & Kokus & Circular & $\begin{array}{l}\text { Putih } \\
\text { susu }\end{array}$ & $\begin{array}{l}\text { Smooth } \\
\text { shiny }\end{array}$ & Entire & Raised & Moist & ++ & M \\
\hline $\mathrm{N} 1 \mathrm{C}$ & Negatif & $\begin{array}{l}\text { Basil } \\
\text { panjang }\end{array}$ & $\begin{array}{l}\text { Circular } \\
\text { punctiform }\end{array}$ & $\begin{array}{l}\text { Putih } \\
\text { krem }\end{array}$ & $\begin{array}{l}\text { Smooth } \\
\text { shiny }\end{array}$ & Entire & Raised & Moist & + & M \\
\hline N2 & Positif & $\begin{array}{l}\text { Basil } \\
\text { panjang }\end{array}$ & Irregular & $\begin{array}{l}\text { Putih } \\
\text { krem }\end{array}$ & $\begin{array}{l}\text { Smooth } \\
\text { shiny }\end{array}$ & $\begin{array}{l}\text { Lobus, } \\
\text { filamentous }\end{array}$ & Raised & Moist & + & M \\
\hline
\end{tabular}

\section{Keterangan :}

$++:$ Katalase positif kuat

+ : Katalase positif lemah

$\mathrm{T}:$ Termofilik

M : Mesofilik 
Karakteristik morfologi BAL nira segar sebagai berikut: N1A memiliki karakteristik gram negatif, bentuk sel basil pendek; bentuk koloni irregular, warna koloni putih susu, permukaan rough, elevasi convex, tepi entire, tekstur $d r y$, katalase positif kuat (++), dan mesofilik; N1в memiliki karakteristik gram positif, bentuk sel kokus, bentuk koloni circular, warna koloni putih susu, permukaan smooth shiny, tepi entire, elevasi raised, tekstur moist, katalase positif kuat (++), dan mesofilik; N1c memiliki karakteristik gram negatif, bentuk sel basil panjang, bentuk koloni circular punctiform, warna koloni putih krem, permukaan smooth shiny, tepi entire, elevasi raised, tekstur moist, katalase positif lemah (+), dan mesofilik; dan N2 memiliki karakteristik gram positif, bentuk sel basil panjang, bentuk koloni irregular, warna koloni putih krem, permukaan smooth shiny, tepi lobus dan filamentous, elevasi raised, tekstur moist, , katalase positif lemah (+), dan mesofilik (gambar 1).

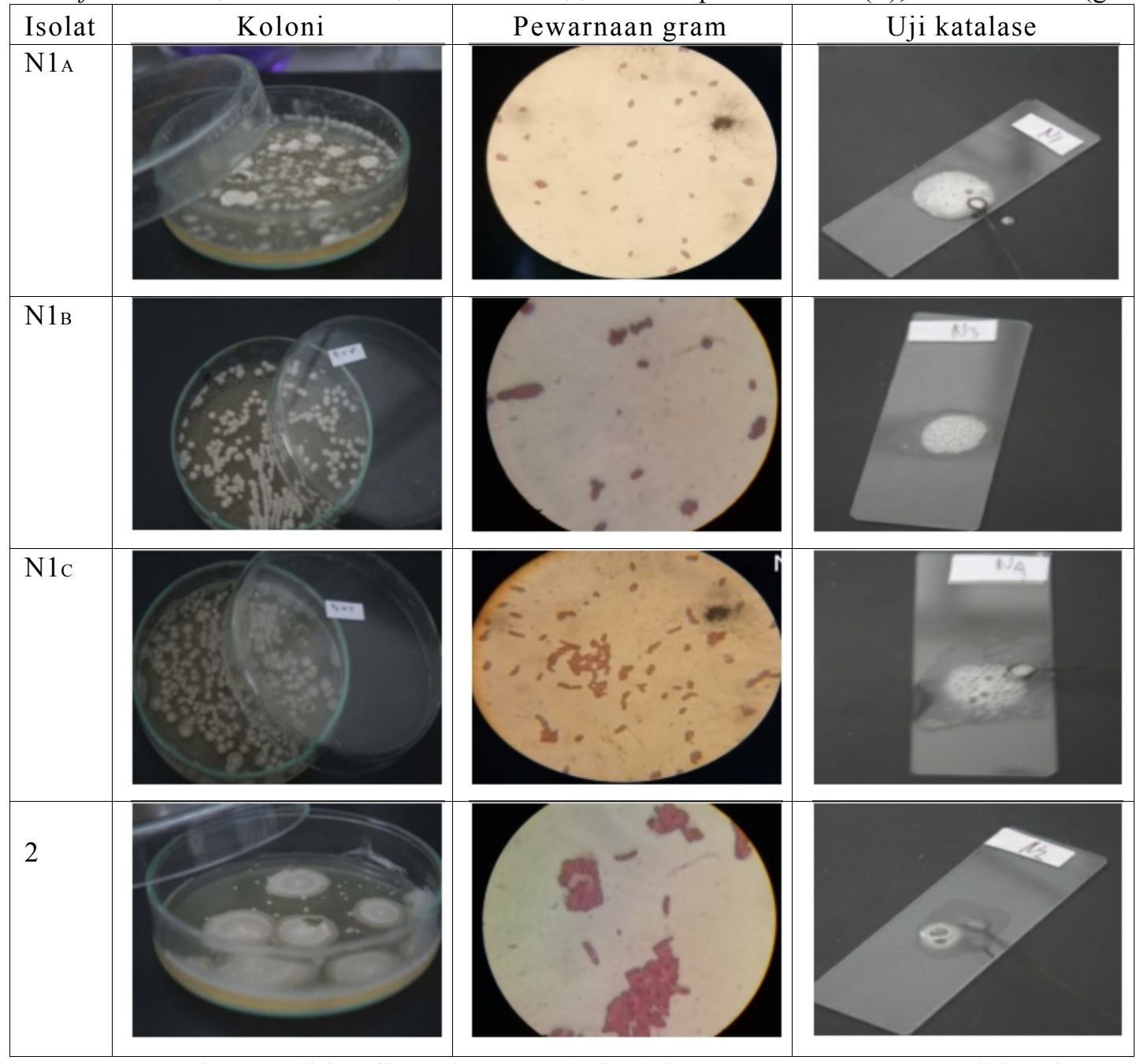

Gambar 1. Uji konfirmasi BAL a) koloni, b) Pewarnaan gram, c) Uji katalase

\section{Identifikasi BAL dari nira segar lontar dengan pewarnaan gram}

Uji pewarnaan Gram BAL diperoleh yaitu bakteri Gram negatif dan bakteri Gram positif. Putri dkk, (2018) menyatakan bahwa pada bakteri Gram positif dapat mempertahankan warna crystal violet warna ungu karena sebagian besar dinding selnya lebih banyak mengandung peptidoglikan sedangkan bakteri gram negatif warna ungu akan tercuci dan mampu mempertahankan warna merah muda karena kandung peptidoglikan yang lebih sedikit.

Dalam penelitian didapati BAL memiliki Gram (+) dan Gram (-). Menurut Surono (2004), menjelaskan karakteristik normal BAL adalah bakteri Gram positif. Cullimore (2000) menyatakan bakteri asam laktat 
memiliki sifat gram positif tetapi ada juga yang bersifat bipolar yaitu memiliki gram positif dan gram negatif yang terjadi akibat adanya granulasi dalam sel dan dipengaruhi oleh umur kultur.

Bentuk sel BAL yang diamati di bawah mikroskop cahaya 100x100 diperoleh bahwa 3 isolat memiliki bentuk basil dan 1 isolat berbentuk kokus. Berdasarkan karakter bentuk selnya, BAL terdiri dari 2 famili. Famili Lactobacillaceae yang berbentuk batang/basil dan famili Streptococcoceae yang berbentuk bulat/kokus (Qonita dkk, 2018). Isolat yang berbentuk batang termasuk famili Lactobacillaceae yaitu genus Lactobacillus dan yang berbentuk bulat/kokus termasuk dalam famili Streptocococeae yaitu genus Enterococcus, Leuconostoc, Pediococcus dan Streptococcus (Qonita dkk, 2018). Sehingga BAL nira segar diperoleh bahwa isolate yang berbentuk sel basil diduga merupakan genus Lactobacillus. Menurut Ray (2001), menyatakan Lactobacillus memiliki ciri-ciri yaitu selnya berbentuk batang dengan ukuran yang sangat beragam. Beberapa memiliki ukuran panjang dan beberapa spesies lain memiliki bentuk yang pendek. Pewarnaan gram Lactobacillus umumnya adalah gram positif dan sebagian saja yang gram negatif. Sedangkan BAL yang berbentuk bulat dan gram positif diduga berupa Enterococcus, Leuconostoc, Pediococcus dan Streptococcus.

\section{Identifikasi sifat biokimia BAL dari nira segar lontar dengan uji katalase dan uji suhu}

Uji katalase merupakan salah satu uji untuk mengidentifikasi mikroba yang mampu menghasilkan enzim katalase dibuktikan dengan terbentuk atau tidaknya gelembung $\left(\mathrm{O}_{2}\right)$ pada saat isolat yang ditetesi $\mathrm{H}_{2} \mathrm{O}_{2}$ (Qonita dkk, 2018). Berdasarkan hasil penelitian diperoleh bahwa semua isolat memiliki katalase positif, ditandai dengan terbentuknya gelembung setelah ditetesi $\mathrm{H}_{2} \mathrm{O}_{2}$. Whittenbury (1964 dalam Putri dkk, 2018) menyatakan bahwa beberapa spesies Lactobacillus, Leuconostoc, Streptococcus, dan Pediococcus dapat menghasilkan katalase positif tergantung pada jenis mikroorganisme dan media pertumbuhannya. Hal ini dapat dijelaskan bahwa media Agar MRS mengandung hematin sehingga bakteri mampu mensintesis apoenzim, serta adanya korelasi antara aktivitas pemisahan $\mathrm{H}_{2} \mathrm{O}_{2}$.

Enzim katalase yang memecah $\mathrm{H}_{2} \mathrm{O}_{2}$ terjadi saat respirasi, dimana bakteri membentuk suatu sistem pertahanan dari toksik $\mathrm{H}_{2} \mathrm{O}_{2}$ yang dihasilkannya sendiri (Anastiawan, 2014). Dari hasil penelitian dapat diduga bahwa ke-empat isolat yang diperoleh tergolong genus Lactobacillus, Leuconostoc, Streptococcus dan Pediococcus.

Berdasarkan kategori pertumbuhan pada suhu tertentu, BAL terdiri dari 2 jenis yaitu mesofilik yang tumbuh optimum pada suhu $250^{\circ} \mathrm{C}$ dan tumbuh maksimum pada suhu $37-40{ }_{0} \mathrm{C}$ dan termofilik yang tumbuh optimum pada suhu 40-450C, dan suhu maksimumnya adalah 45- 520 C (Surono, 2004). BAL yang diperoleh dari nira segar termasuk jenis mesofilik karena mampu tumbuh pada suhu 25-370C dan tidak tumbuh pada suhu $400_{0} \mathrm{C}$. Bakteri yang tergolong mesofilik pada penelitian ini diduga yaitu, Lactobacillus, Enterococcus, Leuconostoc dan Pediococcus (Putri dkk, 2015).

Penelitian Ouoba et al., (2012) berhasil mengisolasi beberapa species BAL dari Borassus akeassii di Africa Barat, dimana hasil identifikasi menggunakan metode 16 rRNA ditemukan bahwa Lactobacillus plantarum adalah species BAL yang dominan. Selain itu juga ditemukan Leuconostoc mesenteroides, Fructobacillus durionis and Streptococcus mitis. Berdasarkan hasil identifikasi bakteri asam laktat dari nira segar lontar diperoleh empat isolat tunggal BAL dengan beberapa karakteristik morfologi yang diamati melalui pewarnaan gram, uji biokimia yakni uji katalase dan uji pertumbuhan pada suhu yang berbeda sehingga dapat diduga bahwa BAL tersebut berasal dari genus Lactobacillus, Enterococcus, Leuconostoc, Streptococcus dan Pediococcus. Hasil penelitian ini memerlukan uji genetik untuk mengkonfirmasi hasil temuan yang ada.

\section{KESIMPULAN}

Dari hasil isolasi mikroba pada nira segar dan identifikasi diperoleh empat isolat BAL tunggal. yakni N1A bentuk basil pendek, gram negatif, katalase positif, dan mesofilik; N1в bentuk kokus, gram positif, katalase positif dan mesofilik; N1c bentuk basil panjang, gram negatif, katalase positif, dan mesofilik; N2 bentuk basil panjang gram positif, katalase positif, dan mesofilik. Berdasarkan karakteristik morfologi ke-empat isolat BAL tersebut diduga merupakan ciri dari genus Lactobacillus, Enterococcus, Leuconostoc, Streptococcus dan Pediococcus.

\section{Referensi}


Anastiawan. (2014). Isolasi dan Karakterisasi Bakteri Probiotik yang Berasal dari Usus Itik Pedaging Anas domesticus. Skripsi. Jurusan Biologi Fakultas Matematika dan Ilmu Pengetahuan Alam, Universitas Hasanuddin.

Cahyaningsih, H.E. (2006). Identifikasi Bakteri Asam Laktat dari nira lontar serta aplikasinya dalam mereduksi Salmonella typhimurium dan Aspergillus flavus pada bijih kakao. Skripsi. Sekolah Pascasarjana, Institute Pertanian Bogor.

Christopher, K \& Bruno, E. (2003). Identification of bacteria species. Alberta, Canada: Departement of Biological Sciences University of Alberta Edmonton.

Cullimore, R.D. 2000. Principal Atlas For Bacterial Identification. Lewis Publisher. United States of America.

Djide, M.N \& Wahyudin, E.. (2008). Isolasi Bakteri Asam Laktat dan Air Susu Ibu dan Potensinya Menurunkan Kadar Kolestrol secara In-Vitro. Majalah Farmasi dan Farmalogi 12(3):-73-78.

Fachrial, A.H. (2018). Isolasi dan aktivitas antimikroba bakteri asam laktat dari fermentasi nira kelapa sawit. Jurnal Biologi Lingkungan, Industri, Kesehatan Vol (5).Fakultas kedokteran dan Fakultas Agro, Universitas Prima Indonesia. Biolink.

Jenie, S.L., dan Shinta E. Rini. 1995. Aktivitas Antimikroba dari Beberapa Spesies Lactobacillus terhadap Mikroba Patogen dan Perusak Makanan. Buletin Teknologi dan Industri Pangan, 7(2) : 46-51.

Naiola, E. (2008). Mikrobia amilolitik pada nira dan laru dari Pulau Timor, Nusa Tenggara Timur. Biodiversitas.

Ouobal, L.I.I., Kando, C., Parkouda, C., Sawadogo-Lingani, H., Diawara, B., \& Sutherland, J.P. (2012). The microbiology of Bandji, palm wine of Borassus akeassii from Burkina Faso: identification and genotypic diversity of yeasts, lactic acid and acetic acid bacteria. doi: 10.1111/jam.12014

Putri, A.A., Erina., \& Fakhrurrazi. (2018). Isolasi bakteri asam laktat genus Lactobacillus dari feses rusa sambar (Cervus unicolor). JIMVET E-ISSN 2540-9492. Maret 2018, 2 (1) : 170-176. Program Studi Pendidikan Dokter Hewan Fakultas Kedokteran Hewan Universitas Syiah Kuala. Laboratorium Mikrobiologi Fakultas Kedokteran Hewan Universitas Syiah Kuala.

Putri, B.S.P., Suwasono, S., \& Choiron, M.. (2015). Identifikasi bakteri asam laktat sebagai anti kapang dari fermentasi kakao di Gunung Kidul Yogyakarta. Jurnal Berkala Ilmiah Pertanian. Volume 10 (10): 23.

Qonita, S.B., Johan, V.S., \& Rahmayuni. (2018). Identifikasi Genus Bakteri Asam Laktat Dari Nira Aren Terfermentasi Spontan. Jurnal Jom Faperta Vol 5, No 1. April 2018. Program Studi Teknologi Hasil Pertanian, Jurusan Teknologi Pertanian, Fakultas Pertanian, Universitas Riau.

Ray, B. (2001). Fundamental Food Microbiology. 3rd Edition. Florida: CRC Press LCC.

Surono, I.S. 2004. Probiotik susu fermentasi dan kesehatan. Jakarta: Tri Cipta Karya.

Suriawiria. 1995. Pengantar Mikrobiologi Umum. Bandung: Angkasa.

Whittenburry, R. 1864. Hidrogen Perioksida Formation And Catalase Aktivity Inthe Lactic Acid Bakteria. Jurnal general mirobial. 35:12-36 